\title{
The Effect of Market and Entrepreneurial Orientation on Firm Performance
}

\author{
*Salima Hafeez, Rashid Mehmood Chaudhry, Zafar Ullah Siddiqui, Kashif Ur Rehman \\ Iqra University, Islamabad, Pakistan \\ *salimahafeez@yahoo.com
}

\begin{abstract}
Market orientation (MO) and Entrepreneurial orientation (EO) have gained the importance in today's world. Now these two are considered the main sources in the increase of firm performance. A corelation analysis is performed to understand and determine whether the market orientation and entrepreneurial orientation is associated with the firm performance. The Past studies did not analyze the effect of MO and EO on the firm performance. The research design and methodology adopted is given together with the findings leading to the conclusions related to propositions concerning the variables. The data is collected from various reputed universities that are giving the business education. Entrepreneurial orientation and market orientation provides the basic knowledge about the organizational learning that enables the organization to achieve the high performance and to understand the values of customers (Liu et al, 2002). The paper draws on survey data from 100 students including male and female students. The results show that EO and MO are strongly co-related with dependent variable. However, a few recommendations and future research is also given.
\end{abstract}

Keywords: Entrepreneurial orientation, Market orientation, Firm performance, Innovations, Proactiveness, customers

\section{Introduction}

The focus of this research is that how entrepreneurial orientation and markets orientation affects the firms performance. As market oriented has different perspectives that focus the customer, competitive intelligence, and crossfunctional intelligence and performance implication. A business is market oriented when its culture is systematically and entirely committed to continue creation of superior customer value. The decisionmaking perspectives are market intelligence perspective, culturally based behavioral perspective, strategic perspective and the customer orientation perspective (Jaworski \& Kohli, 1993). The model developed by the Slater and Narver (2000) consists of the three components which are customer competitor, competitor orientation and interventional coordination. Importantly, the market orientation is involved to use the superior organizational skills in understanding and satisfying the customers. Kohli and Jaworski (1990) stated that three main features of the marketing orientation marketing concepts: (1) customer focus, (2) coordinated marketing, and (3) profitability.

The market orientation is focuses the current and future needs of the customer, increase the level of intelligence in the organization and make the organization for the responsiveness (Kohli and Jaworski, 1990:6). It is necessary to understand the conditions through which the entrepreneurial orientation increases the firm performance may thus require a contingency perspective that emphasizes the importance of fit among a firm's strategic attitude and other constructs of interest (Lumpkin \& Dess, 1996). The limited experiential proof that exists suggests that although networks may facilitate the performance of entrepreneurial firms, not all ties do so equally (Peng \& Luo, 2000). Therefore, the condition through which the particular relationship enhances shows an important research agenda (Lee, Lee, \& Pennings, 2001). This article is organized as follows: the conceptual framework of antecedents and consequences of market orientation will be described. This is followed by a description of the methodology and empirical analysis. Then, it concludes with a discussion of the key results, limitations, and directions of the research.

\section{Theoretical Framework}

Entrepreneurial Orientation: Entrepreneurial orientation is defined as the processes, structures, and behaviors of firms that are characterized by innovativeness, proactiveness, and risk taking (Covin \& Slevin, 
1989; Miller, 1983). Despite the possibility that the aforesaid variables mentioned may differ from one and other (Lumpkin \& Dess, 2001), we view entrepreneurial orientation as the instantaneous display of innovativeness, proactiveness, and risk taking and thus focus on the performance implications of a firm's overall entrepreneurial stance. Entrepreneurial orientation has become an essential concept in the domain of entrepreneurship that has received a considerable amount of theoretical and empirical attention (Covin, Greene, \& Slevin, 2006). Drawing on prior strategy making process and entrepreneurship research, measurement scales of EO have been developed and widely used, and their relationships with other variables have been examined. Thus, EO represents one of the areas of entrepreneurship research where a cumulative body of knowledge is developing. The focus of entrepreneurial orientation is towards the strategy making process that gives a direction to the organization for the entrepreneurial decision and actions (e.g., Lumpkin \& Dess, 1996; Wiklund \& Shepherd, 2003).

Firm performance is defined as the extent to which the firm's financial and other objectives are achieved through execution of tactics, marketing strategies, and management. EO represents one of the areas of entrepreneurship research where a cumulative body of knowledge is developing. Consequently, we believe that the time has come to document, review, and evaluate the cumulative knowledge on the relationship between EO and business performance. The role of the entrepreneurial orientation is clearly shows in the strategy making process literature (e.g., Mintzberg, 1973). The strategy making is an important part of an organization, which consists of planning, analysis, decision-making and many aspects of an organization's culture, value system, and mission. The significant scope of EO can be obtained from a review and integration of the strategy and entrepreneurship literatures (e.g., Covin \& Slevin, 1991; Miller, 1983; Miller \& Friesen, 1978; Venkatraman, 1989a). The Miller's (1983) according to his research has identified three dimensions of entrepreneurial orientation, innovativeness, risk taking, and proactiveness, which are using in literature continuously. Innovativeness is tendency to engage in the creativity and innovations of the new products and through using the new technology. Risk taking is the name of bold action taken in an un-certain environment.

The companies can take the benefits by adopting the entrepreneurial orientation. Such companies are always go for the innovation regularly taking risk as per their formulated product market strategy (Miller \& Friesen, 1982). Making the efforts to fulfillment of demand as per requirement and quickly positioning of new product increases the performance of a firm (Ireland, Hitt, \& Sirmon, 2003). The research study found that the performance of the organizations which implements the entrepreneurial orientation more is better then those who do not adopt the EO (with an r >.30, e.g., Covin \& Slevin, 1986; Hult, Snow, \& Kandemir, 2003; Lee, Lee \& Pennings, 2001; Wiklund \& Shepherd 2003), while some studies show that there is low co-relation of EO with the performance (i.e., Dimitratos, Lioukas, \& Carter, 2004; Lumpkin \& Dess, 2001) and research also unable to show any significant co-relation between EO and performance (George, Wood, \& Khan, 2001; Covin, Slevin, \& Schultz, 1994). The results of study showed entrepreneurial strategy making was strongly related to firm performance when it was combined with both proper strategy and environment. Covin and Slevin's (1989) study also suggested that EO is related to performance among small firms in hostile environments. The past research shows that entrepreneurial orientation has positive co-relation with the firm performance (Covin Slevin, 1989; Lumpkin \& Dess, 1996; Wiklund, 1999; Lee \& Peterson, 2000).

H1: There is a positive co-relation between the entrepreneurial orientation and firm performance.

Market Orientation: In order to get better performance and to improve the performance of the companies, the top management relied on the market orientation. The market orientation is the process of creating superior value and increasing performance (Slater and Narver, 2000). The basic concept of this market orientation is to satisfy the customer needs and requirements for the improvement of business performance. Market orientation consist of wide generation of market intelligence that pertain the current and future customers needs and disseminate that needs into responsiveness. MO has been described that implementation of marketing activities that is designed to better understand customer needs to competitors and able to satisfy customer needs (Martin and Grbac, 2003). The main features of the market orientation according to the cultural perspective are to give the customer importance and give the superior value to a customer Narver and Slater (2000). Conceptual model developed by includes three behavioral components of MO: customer orientation, competitor orientation and interventional coordination. All of them are incorporated in intelligence generation and dissemination. MO also includes long-term focus and profitability 
as the decision criteria. In the market orientation there are three components i.e. customer focus, competitor focus and interfunctional coordination. All components have focus on information gathering, information dissemination and capability to respond about what is received (Baker and Sinkula, 1999). Kohli and Jaworski (1990) define the market orientation in the three dimensions:

- The gathering of market information and understanding about needs of customers and external environmental factors

- The dissemination of that information along with organizational functions

- Formulation and implementation of those strategies in response to the given information.

These components having the continuous and systematic information gathering process about customers, competitors and cross-functional coordination of marketing activities according to the changing customers needs (Martin and Grbac, 2003). Researcher found the positive relationship between the market orientation and the business profitability where MO is more focusing on the customer and competitor (Slater and Narver, 2000). The entrepreneurial orientation emphasis upon the risk taking, innovativeness and competitiveness that may identify the unnerved market segment (Lumpkin and Dess, 1996; Slater and Narver, 2000). Identified significant, positive links between market orientation and overall performance. The consumer orientation is similar in definition to a "market orientation" as defined by Kohli and Jaworski (1993) because it begins and ends with the needs of the customer. MO enables the firms to understand the market, and according to the customer needs and wants, they develop the strategy about the product and services (Liu et $\mathrm{al}, 2002$ ). MO assures the customer focused strategy, by acquiring the market knowledge, coordination and the interfunctional marketing efforts by achieving the organizational objectives.

The survey so far conducted and the past research concluded that market orientation play an important role in innovation of firm as well as the firm performance. Marketing and market orientation has been a great debate and inside the marketing, market orientation always been important and useful as an intangible factor which effect the firm performance (Homburg et al., 2003). Market orientation is the implementation of the marketing concept. Being marketing orientated is more than just being customer-led. It requires the full support of the organization to be fully implemented in the long term and, indeed, may need a complete change in an organization's culture. The organizations take the market orientation important and now it has become a culture of the organizations that requires customer satisfaction and an important source of business operation (Liu et al, 2002). Accordingly, it satisfies the customer needs and improves the firm performance (Narver and Slater, 2000). The focus in market is a customer so with the passage of time the customer's needs and requirements get change and in order to cope with such change, the introduction of new products with good quality and it improves the firm performance (Jaworski and Kohli, 1993). The changing markets always demand for the introduction of new product and services alongwith the innovation to the firm. The market orientation also act to implement the activities being carried out in the market in order to satisfy the customers need better then that of competitors (Martin and Grbac, 2003). The several researches have been conducted and concluded that there is positive co-relation between market orientation and the performance of the firms. Even though the several studies have linked a strong relationship between the market orientation and the profit link between market orientation and innovation appears to be more complex (Martin and Grbac, 2003; Slater and Narver, 2000). The conceptual research suggested that the market orientation is beneficial for the firm depends upon the environmental factors (Narver and Slater, 1990). The companies are required to be focused by the strong market orientation on those environmental elements, which increases the ability for the customer satisfaction relative to competitors (Baker and Sinkula, 1999). Kohli and Jaworski (1993), for example suggest that market orientation may not have critical importance in unstable environments. The latest research indicates that the relationship between the market orientation and the firm performance is not effected by the environmental factors (Jaworski and Kohli, 1993).

H2: $\quad$ Market orientation has positive impact on the firm performance. 
Research Model:

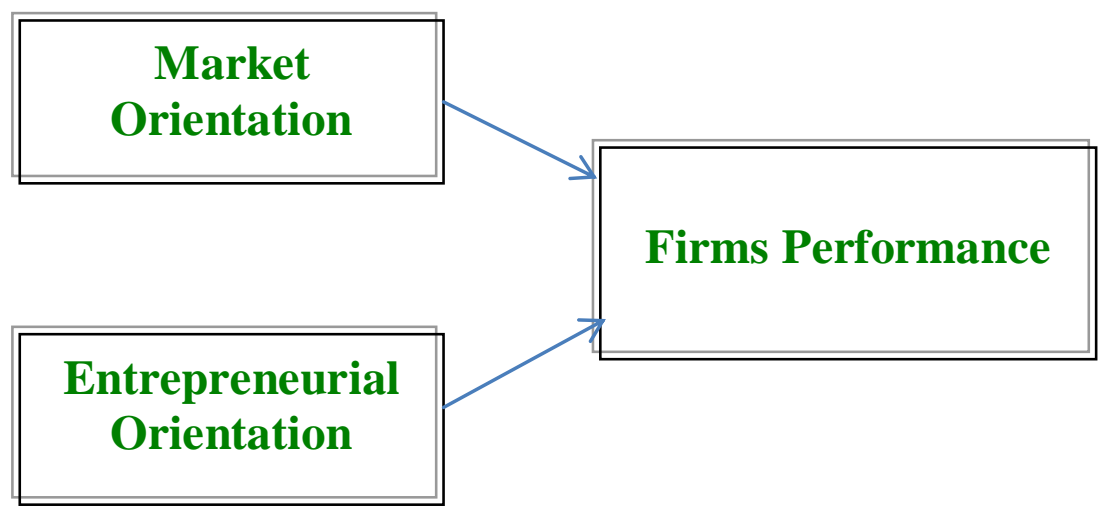

\section{Methodology}

Exploratory and confirmatory factor analyses were used to test Hypotheses $\mathrm{H} 1$ and $\mathrm{H} 2$. The data collected from the different universities and hypotheses have examined through this data, which is filled by the university students. The data collected from both the public and private universities, which are well known in delivering the business education. These universities are well recognized and approved by the Higher Education Commission in Pakistan. A questionnaire distributed to 100 students including male and female students. These students are of graduate, postgraduate and of $\mathrm{PhD}$ levels. $63 \%$ of the total respondents were male and $37 \%$ female. Our focus is to analyze the two components (Market Orientation and Entrepreneurial Orientation with Firm Performance. Teams are engaged in a various task performed by the member. We present the methodology and findings of this research by the integration and the discussion with the research members. The respondents were given the choice to mark the appropriate answer. Hence the respondents must select and circle between strongly disagree to strongly agree i) Strongly Disagree (SD), ii) Disagree (D), iii) Neutral (N), iv) Agree (A), Strongly Agree (SA). Past studies showed the impact of the psychological traits of owners and managers on firm level entrepreneurial orientation (Krauss et al, 2005; Entrialgo et. al; 2000). Thus, we measured the owner's entrepreneurial orientation for organization's entrepreneurial orientation. Market orientation was measured using Narver and Slater (1990) measurements. In order to examine the relationship between MO and EO with the firm performance, various statistical tools were used. First, multiple regression analyses were used to identify which dimensions of MO and EO influence the performance of firm. Then, Independent sample t-tests were conducted to differentiate the two groups by comparing the mean scores of their performance. The data were analyzed by using SPSS 15.0 statistical program and factor analysis, reliability and correlational analyses were utilized in order to evaluate the relationships between the variables.

\section{Results of Analysis}

Table 1: Respondents Profile

\begin{tabular}{|c|c|c|}
\hline \multicolumn{3}{|c|}{ Frequency $(\mathrm{N}=100)$} \\
\hline & $\mathbf{N}$ & \%age \\
\hline \multicolumn{3}{|l|}{ Gender } \\
\hline Male & 63 & 63 \\
\hline Female & 37 & 37 \\
\hline \multicolumn{3}{|l|}{ Age } \\
\hline Below 30 & 64 & 64 \\
\hline $30-50$ & 36 & 36 \\
\hline 51 above & Nil & Nil \\
\hline \multicolumn{3}{|l|}{ Education } \\
\hline Below Graduate & Nil & Nil \\
\hline Graduate & 33 & 33 \\
\hline Post-graduate & 20 & 20 \\
\hline PhDs & 47 & 47 \\
\hline
\end{tabular}


Table 2: Description of Measures

\begin{tabular}{llllll}
\hline Variables & Mean & Kurtosis & Std. Dev. & Skewness & $\begin{array}{l}\text { Cronbach's } \\
\text { Alpha }\end{array}$ \\
\hline Market Orientation & 3.4650 & -0.8653 & 0.57881 & -0.4970 & 0.7835 \\
Entrepreneurial Orientation & 3.7968 & -0.2650 & 0.59886 & -0.0840 & 0.7845 \\
Firms Performance & 3.7600 & -0.15221 & 0.62603 & -0.599 & 0.8356 \\
\hline
\end{tabular}

Table 3: Hypotheses testing based on Regression weights

\begin{tabular}{lllll}
\hline Variables & Beta & sig. & T-value & Results \\
\hline FP $\leftarrow$ MO & 0.619 & 0.000 & 6.313 & Accepted \\
FP $\leftarrow$ EO & 0.232 & 0.004 & 2.808 & Accepted \\
\hline
\end{tabular}

\begin{tabular}{lllll}
\hline R square & $\begin{array}{l}\text { Adjusted } \\
\text { square }\end{array}$ & $\begin{array}{l}\text { R } \\
\text { of square }\end{array}$ & $\begin{array}{l}\text { Residual sum of } \\
\text { square }\end{array}$ & Sig. \\
\hline 0.479 & 0.465 & 18.122 & 20.678 & 0.000 \\
\hline
\end{tabular}

A total sample (n) of 100 students was taken and questionnaires were personally administrated. The ratio of male and female respondent was $63 \%$ and $37 \%$ respectively. $30 \%$ respondents were from Air University Islamabad, $45 \%$ from Iqra University Islamabad and remaining $25 \%$ were from COMSATS University Islamabad. The reliability of the scale can be seen in table 02 where value of the Cronbach's Alpha for each variable is given. Total three (3) variables used which were Market Orientation, Entrepreneurial Orientation as independent variable and Firm Performance as dependent variable. Five point likert (1.strongly disagree, 2. disagree, 3. neutral, 4. agree, 5. strongly agree) was used. The mean value for the MO was 3.4650 , for EO it was 3.7968, and for FP is 3.7600 . For MO, the co-relation value is significant $(\mathrm{P} \leq 0.01)$ which shows the corelation with the other variables. The Standard Deviation of MO is 0.57881 , for EO is -0.0840 and for FP, it is 0.62603 . The value of $\beta$ is 0.619 which shows that the coefficients and its importance that its significance value is 0.000 which is supporting to $\mathrm{H} 1$ i.e. Market Orientation has strong influence on the firm The value of $ß$ for EO is 0.242 with significance value is 0.004 which shows positive relationship between entrepreneurial orientation and firm performance which is supporting to $\mathrm{H} 2$.

\section{Discussion and Conclusion}

The main objective of this study was to provide the importance of market and entrepreneurial orientation on the firm performance. The market and entrepreneurial orientation now days have become important for the firms performance. The main features of the market orientation are the customer focus, competitor intelligence focus, cross-functional coordination and performance implication. The above result shows that the market orientation has strong co-relation with the firm performance. The relationship between market orientation and business performance is significant and positive in case of profitability and economic performance. The market orientation is the process of creating superior value and increasing performance (Slater and Narver, 2000). The question arises that whether the firms are following the market and entrepreneurial orientation? As a result, execution of a market-oriented strategy, reacting to market feedback may allow a firm to adapt successfully to external environmental changes. However, while a strong market orientation may keep a firm on a steady course, alone, it may not necessarily constitute a dominant market position for the firm. The companies are required to be focused by the strong market orientation on those environmental elements, which increases the ability for the customer satisfaction relative to competitors (Baker and Sinkula, 1999). Kohli and Jaworski (1990).

The firms, which are more market oriented, are closer to understand the customer need and requirement. The second variable was the entrepreneurial orientation whether this effect the firm performance or not. However, after going through the analysis it is revealed that it has strong co-relation with the firm 
performance. The past research shows that entrepreneurial orientation has positive co-relation with the firm performance (Covin Slevin, 1989; Lumpkin \& Dess, 1996; Wiklund, 1999; Lee \& Peterson, 2000). Empirically, this study enhances understanding of how entrepreneurial orientation and social capital shape the performance of new ventures in emerging industries (cf. Aldrich \& Fiol, 1994). Failing to support some previous arguments that adopting a strong entrepreneurial orientation early in an industry's life cycle generates valuable first mover advantages (Lumpkin \& Dess, 2001), weak main effects of entrepreneurial orientation on performance emerged here.

Limitation and future research: Our meta-analysis has some limitations. These limitations can be attributed in part to the limitations of the underlying studies leading to suggestions for improvements in future studies. Since the data was collected only limited numbers of students from few universities, It would be meaningful in the future if future research would conduct empirical research by surveying on a wider range of business types. Further, the future research may also be conducted by adding another independent variable e.g. customer orientation and its effect on the firms performance alongwith the other variables.

\section{References}

Aldrich, H. E. \& Fiol, C. M. (1994). Fools rush in. The Institutional context of industry creation. Academy of Management Review, 19, 645-670.

Baker, W. E. \& Sinkula, J. M. (1999). The Synergistic Effect of Market Orientation and Learning Orientation on Organizational Performance. Journal of Academy of Marketing Science, 27(4), 411-427.

Covin, J. G. \& Slevin, D. P. (1989). Strategic management of small firms in hostile and benign environments. Strategic Management Journal, 10, 75-87.

Covin, J. G., Green, K. M. \& Slevin, D. P. (2006). Strategic process effects on the entrepreneurial orientation sales growth rate relationships. Entrepreneurship Theory and Practice, 30(1), 57-81.

Dimitratos, P., Lioukas, S. \& Carter, S. (2004). 'The relationship between entrepreneurship and international performance: The importance of domestic environment. International Business Review, 13(2).

George, G., Wood, D. R. J. \& Khan, R. (2001). Networking Strategy of Boards: Implications for Small and Medium-Sized Enterprises. Entrepreneurship-and-Regional-Development, 13(3), 269-285.

Homburg, C., Krohmer, H. \& Workman, J. P. (2003). A Strategy Implementation Perspective of Market Orientation. Journal of Business Research, In Press, Corrected Prof, Available Online May 2003.

Hult, G. T. M., Snow, C. C. \& Kandemir, D. (2003). The role of entrepreneurship in building cultural competitiveness in different organizational types. Journal of Management, 29(3), 401-426.

Ireland, R. D., Hitt, M. A. \& Sirmon, D. G. (2003). A model of strategic entrepreneurship: The construct and its dimensions. Journal of Management, 29, 963-989.

Jaworski, B. J. \& Kohli, A. K. (1993). Market Orientation Antecedents and Consequences. Journal of Marketing, 57, 53-70.

Lee, C., Lee, K. \& Pennings, J. M. (2001). Internal capabilities, external networks, and firm performance: A study on technology-based ventures. Strategic Management Journal, 22, 615-640.

Liu, S. S., Luo, X. \& Shi, Y. (2002). Integrating Customer Orientation in Organizations -in- Transition: An Empirical Study. International Journal of Research in Marketing, 19, 367-382.

Lumpkin, G. T. \& Dess, G. G. (1996). Clarifying the entrepreneurial orientation construct and linking it to performance. Academy of Management Review, 21, 135-172.

Lumpkin, G. T. \& Dess, G. G. (2001). Linking two dimensions of entrepreneurial orientation to firm performance: The moderating role of environment and industry life cycle. Journal of Business Venturing, 16, 429-451.

Martin, J. H. \& Grbac, B. (2003). Using Supply Chain Management to Leverage a Firm's Market Orientation. Industrial Marketing Management, 32, 25-38.

Miller, D. (1983). The correlates of entrepreneurship in three types of firms. Management Science, 29, 770791.

Mintzberg, H., Raisinghani, D. \& Theoret, A. (1976). The structure of unstructured decision processes. Administrative Science Quarterly, 21, 246-275.

Miller, D. \& Friesen, P. H. (1982). Innovation in conservative and entrepreneurial firms: Two models of strategic momentum. Strategic Management Journal, 3, 1-25. 
Peng, M. W. \& Luo, Y. (2000). Managerial ties and firm performance in a transition economy: The nature of a micro-macro link. Academy of Management Journal, 43, 486-501.

Slater, S. F. \& Narver, J. C. (2000). Market Oriented is More Than Being Customer-Led. Strategic Management Journal, 20, 71-80.

Venkatraman, N. (1989). Strategic orientation of business enterprises: The construct, dimensionality, and measurement. Management Science, 35(8), 942-962.

Wiklund, J. \& Shepherd, D. (2003). Knowledge-based resources, entrepreneurial orientation, and the performance of small and medium sized businesses. Strategic Management Journal, 24, 1307-1314. 